\title{
The Financing and Capital structure of Small and Medium- SCALE ENTERPRISES: THE IMPORTANCE OF ENTERPRISE Characteristics and Gender Financing Constraints
}

S O Migiro

Department of Business Management, University of Zululand

\begin{abstract}
This paper investigates the determinants of the financing structure of SMEs. The evidence on SMEs' financing structure is based on existing empirical surveys and literature review. The paper provides testable implications developed from economic finance theory. The presentations in the paper utilise data from a previously unexamined source, complementing existing evidence that has been dominated by studies from more developed countries. The results from the empirical survey reveal that there are strong relationships between enterprise size and age, and SME financing structure.
\end{abstract}

Key words: SMEs' finance, capital structure, SMEs' characteristics, finance and capital structure.

JEL G3-32

\section{1 \\ Introduction}

How business is financed is one of the most fundamental questions of research in SMEs. Finance is one of the necessary resources required to establish SMEs and subsequently operate them successfully. The importance of financing decisions of SMEs consequentially has important implications for the economy, given the role SMEs play in employment growth, competition, innovation and export potential. While research examining the financing of SMEs has increased, there is limited understanding of this area among Kenyan SMEs. Existing literature on the capital structure of Kenyan firms has so far failed to investigate factors associated with SMEs' financing structure. This paper investigates the factors that influence their financing structure, i.e. the determinants of the financing structure of small and medium-sized enterprises. In doing so, we address their financing perspective. Secondly, this study goes beyond merely being descriptive in nature by providing testable implications developed from economic finance theory. In addition to these contributions, this study utilises data from previously unexamined sources, complementing existing evidence that has been dominated by studies from the more developed countries.

The paper is organised as follows: Section 2 describes empirical theoretical perspectives on enterprise finance, while Section 3 provides the empirical results of the study. Finally, the last section draws conclusions and suggests policy measures.

\section{Theoretical perspectives of SMEs' financing structure and literature review}

There has been increasing recognition in recent years that SMEs are different from large-scale enterprises and that these differences affect numerous aspects of their performance, including capital structure. Empirical studies in several countries show that compared to largescale enterprises, SMEs are characterised by: 
- lower and variant profitability (Cosh and Hughes, 1993: 284-315),

- lower liquidity (Gupta, 1969; Chittenden et al., 1996),

- Iower use of long-term debt (Chittenden et al., 1996: 64),

- higher short-term debt (Cosh \& Hughes, 1993: 296).

Capital structure, a crucial aspect in a firm's performance, has occupied financial researchers for a long time. Following Modigliani and Miller's (1958: 277) perfect capital market propositions, many theories on the capital structure of the firm were developed which can be classified into three categories: tax-based theories, agency cost theories and asymmetric information theories. None of these theories, however, distinguishes between small and large firms. Although these theories do not distinguish between SMEs and large-scale enterprises, Myers' pecking order theory as well as the asymmetric information theory provides insights into variations in the capital structure. According to these theories, debt may be more costly than internal sources due to transaction and bankruptcy costs. Moreover, lack of disclosure requirement of information by SMEs makes the problems of information asymmetry more severe for them, causing lenders to rely particularly heavily on collateral to mitigate those problems. In addition, external equity is considered to be more expensive for an SME, also resulting in a loss of control of the enterprise by the original owner-manager. Other empirical studies (Gupta, 1969: 520-26; Bates, 1971: 69; Titman \& Wessels, 1988: 7; Ang, 1992: 18892; Chittenden et al., 1996: 64) suggest that there are differences in the financing structure between SMEs and large-scale enterprises and that debt structure is a function of certain firm characteristics, such as size, profitability, asset structure, collateral, liquidity and age, access to capital markets, risk and growth.

Gupta (1969: 524) looked at the influence of industry, size and growth on the financial structure of corporate enterprises. He found that the total debt/total asset ratio was negatively related to the size of the enterprise. He attributed this to the very high cost of outside equity funds for smaller enterprises and the various psychological factors associated with their management which result in their being reluctant to take in new equity. However, since the smaller-sized enterprises faced almost the same difficulties in obtaining long-term debt as they faced with respect to outside equity, the maturity composition of their debt structure was likely to be shorter than that of larger-sized firms.

Bates (1971: 67) found that small enterprises tended to rely more heavily on their savings than large enterprises; the very largest and the very smallest enterprises tended to finance a large part of capital expenditure from their own savings; capital issues were rare and not very important for small enterprises; small enterprises relied more on bank loans and trade credit; loans from directors were important for small firms but not for large. The Bolton Committee Report (1971) confirmed many of Bates's findings and added further information with regard to the financial characteristics of small, rapidly growing enterprises which it found to be less liquid and more profitable than slowly growing small enterprises.

The Wilson Committee (1979) found great diversity in the financial characteristics and financial performance of small enterprises and that average figures for small enterprises could consequently be quite misleading and needed to be treated with caution. Having made this very important qualification, the Committee reported that while small enterprises appeared to have less equity than large ones, this was less often the case if directors' loans were included. It was noted that small enterprises distributed a much lower proportion of their profits than did large enterprises. The Committee confirmed the findings of Bates and Bolton with regard to the use of bank borrowing, trade creditors and longterm loans.

Storey, Keasey, Watson and Wynarczyk (1987: 94) found the following in the case of small enterprises: greater variability in profits and growth; increasing profitability with increase in size; and that the age of an enterprise was an important factor, with younger 
enterprises being more likely to be more profitable and grow more quickly.

Chittenden, Hall and Hutchinson (1996: 63) looked at the determinants of capital structure for a sample of small enterprises which included both quoted and unquoted firms. Their results showed that profitability, asset structure, size (total assets), age and access to the capital market did affect the capital structure of small firms. While growth did not significantly affect capital structure itself, the combination of rapid growth and lack of access to the capital market did. Access to the capital market itself appeared to be a major factor determining the capital structure of small firms. Once a flotation had been achieved, long-term debt became available and collateral became less important. The pecking order framework emerged as a good explanation of small unlisted firms' capital structure with a heavy reliance on internally generated funds being the key feature. Agency theory also provided explanations which stood up to empirical testing. The use of collateral, especially for unlisted small firms, appeared to be widespread and was consistent with its being used as a way of dealing with agency problems in lending to small firms. Jordan, Lowe and Taylor (1998: 16-24), in addition to looking at size, growth, profitability, asset structure and other financial variables as determinants of capital structure, considered the impact of variables related to enterprise strategy.

Their results strongly supported the propositions that: both financial and strategic factors are necessary to explain enterprise debt levels; industry effects are not important in explaining the capital structure of small firms; capital intensity (asset structure) is negatively related to debt; cash flow is negatively related to debt; innovation strategy is negatively related to debt; SMEs that pursue innovation strategies have lower debt levels than firms that pursue other competitive strategies; and the capital structure of SMEs is consistent with a pecking order approach to capital structure. Their results with regard to the relationship between capital structure and turnover (size) and sales growth were also supported, but less conclusively. Their results strongly rejected the propositions that: profitability is negatively related to debt; the effective tax rate is positively related to debt; and risk is negatively associated with debt. They concluded, with respect to strategy variables, that while the literature provides some weak link between the two, they had been unable to show this in the context of small firms.

3

Methodology

From consideration of the previous studies of the determinants of the capital structure of small enterprises it becomes clear that size, profitability, asset structure, collateral, liquidity, age, access to capital markets, risk and growth are, prima facie, likely to be related to SMEs' financing structure. Amongst them, these items capture most of the variables in the arguments for the life-cycle, pecking order framework and agency theory explanations.

\subsection{Variables}

Four different but related business financing measures were used for the study's dependent variables: leverage, long-term leverage, outside financing and bank financing. These variables were taken either directly from the survey or were created using the sum of different financing options listed in the study. Leverage is simply the total debt of the firm divided by the total assets. Long-term leverage is included and refers to non-current debt.

Several studies have looked specifically at the issuance and level of bank financing at both startup and by existing firms (Freedman \& Godwin, 1994: 34-48; Storey, 1994: 134; Cressy, 1996: 402). Using the bank financing definition is advantageous in that we can observe the behaviour of a particular group of outside financiers to see if they behave differently from conventional financiers (that is, banks). Under the financing categories of outside financing and bank financing adopted by this study, it is not considered relevant whether the capital is provided as a loan or as equity. Hence these variables overcome potential problems associated with the identification of debt and equity or the use of quasi-equity by SMEs in the study (Ang, 1992: 197). 
All the variables employed have been used in previous empirical studies on enterprise finance. Use was made of the field survey data which provided detailed information, including financial statement data on SMEs. The following data were required: number of employees (NE), year of incorporation (YI), sales turnover (TO), fixed assets (FA), current assets (CA), total assets (TA), current liabilities (CL), and long-term loans (LTL).

\subsection{Target population and sample size}

The study target was manufacturing SMEs located within Nairobi, Nakuru, Kisumu and Eldoret, Kenya. The locations were chosen for their diverse manufacturing activities and concentration of enterprises in metal and metal products, textile and garments and wood and wood products. The sampling frame consisted of 940 registered SME operators. All businesses that satisfied the definitional and data requirements for the research were selected through stratified and random sampling, resulting in a sample of 380 SMEs. The sample size was assumed sufficient due to the commonality of the characteristics of the SMEs in the study.

These sampling techniques helped to control bias in the selection process. The final sample size comprised textile and garment (119) respondents, metal and metal products (152) respondents, and furniture and wood products (109) respondents. To collect empirical data, a survey research design was used in which a total of 380 questionnaires were randomly administered. The selected SMEs had three years data (required to calculate the growth rate variable discussed below) for the period 20022004. Tests for the dependent variable to total assets were undertaken using the logit model.

Table 1

Sample size distribution [ $N=940 ; s=$ sample 380].

\begin{tabular}{|l|c|c|c|c|c|}
\hline Textile & & & & & \\
\hline Towns & Nairobi & Nakuru & Kisumu & Eldoret & Total \\
\hline $\mathrm{N}$ & 180 & 15 & 45 & 10 & 250 \\
\hline s & 65 & 13 & 31 & 10 & 119 \\
\hline Metal & & & & 26 & 496 \\
\hline N & 397 & 18 & 55 & 21 & 152 \\
\hline S & 80 & 15 & 36 & & 194 \\
\hline Furniture & 102 & 20 & 55 & 5 & 109 \\
\hline N & 51 & 17 & 36 & 5 & \\
\hline s & & & & & \\
\hline
\end{tabular}

The dependent variables were defined as follows:

Long-term debt $=$ LTL $/$ TA $=$ long-term liabilities /Total Assets (long -term loan)

Short-term debt $=\mathrm{CL} / \mathrm{TA}=$ Current liabilities

Total liabilities (Overdraft, supplier credit and cash advances from customers)

Total debt $=(\mathrm{CL}+\mathrm{LTL}) / \mathrm{TA}$.

The independent variables used were:

Collateral $=$ FA $/ \mathrm{TA}=$ Fixed Assets $/$ Total Assets Size $=$ Number of employees.
Enterprise's age.

Owner-manager's age.

Form of business.

Gender

\subsection{Data analysis}

Data were analysed using the logit model. The model was found suitable because we attempt to examine the financing decisions of a business which are often of non-linear form. Extant researchers have used logit and probit 
techniques to model such decisions. The logit technique can be used to model the relationship between the probabilities of a firm switching from one branch of a financing decision to another, subject to a vector of explanatory variables. For example, Gardiner and Tzcinka (1992) test Myer's (1977) theory of the relationship between a firm's growth opportunities and its debt levels. They do this by estimating a logit model giving the relationship between a firm's growth rate (and other variables) and its probability of choosing all equity financing versus debt and equity. Jordan et al. (1998) apply similar procedures when modelling the impact of corporate strategy on its firm's capital structure.

The logit model is applicable to problems of a binary choice, that is, when a decision has only two possible outcomes. In more general situations, where there are several possible outcomes, or a multi-step decision tree is to be analysed, the probit model is more applicable. For example, Chehab (1995) applies a sequential probit model to investigate the preferred choices of the firm between three or more financing alternatives. This is a special case of a general multi-purpose model since it is used to estimate the successive sequential binary choices. Such an approach is used to investigate the choices of financial sources and the popularity of one source over another in relation to the firm's characteristics.

The logit model does not assume linearity of relationship between the independent variables and the dependent, does not require normally distributed variables, and does not assume homoscedasticity.

The model operates on the premises that $\mathrm{X}$ independent variable(s) have a potential effect on the Y dependent variable(s). Formulae: $L_{i}=\ln \left(\frac{P_{i}}{1-P_{i}}\right)=\beta_{0}+\beta_{1} X_{1 i}+\beta_{2} X_{2 i}$
$+. .+\beta_{n} X_{n i}+\mu_{i}$

Notation and Definitions

$\mathrm{L}_{i}=\ln \left(\frac{P_{i}}{1-P_{i}}\right)$ or $\log$ of the odds ratio

$\mathrm{P}_{\mathrm{i}}=$ represents the proportion of the dependent variable used (or that applies to the situation) and 1- $\mathrm{P}_{\mathrm{i}}=$ Proportion of the specified variable not being used (or not applying to the situation), where $0 \leq P_{i} \leq 1$.

Algebraically, $\mathrm{P}_{\mathrm{i}=} \operatorname{Prob}\left[\mathrm{Y}_{\mathrm{i}}=1\right]=$ $\frac{\exp \left(\alpha+\beta X_{i}\right)}{1+\exp \left(\alpha+\beta X_{i}\right)}$ and

$1-\mathrm{P}_{\mathrm{i}}=\operatorname{Prob}\left[\mathrm{Y}_{\mathrm{i}}=0\right]=\frac{1}{1+\exp \left(\alpha+\beta \mathrm{X}_{\mathrm{i}}\right)}$

$X_{1}, X_{2} \ldots, X_{\mathrm{n}}$ Are the independent (explanatory) variables and could also be dichotomous or otherwise.

$\beta, \ldots, \beta_{n}$ are the coefficients of the independent variables.

$\mu_{i}=$ Disturbance or error term to take into account the influence of other factors not included in the model but which have an effect on the dependent variable.

A priori, the hypothesised signs of the explanatory variables of form of business and enterprise age are expected to be positive, while owner-managers' age, collateral and enterprise size are expected to be positive or negative.

Indeed, collateral and age can be interpreted within corporate finance literature as an entrepreneur's ability to manifest less risk in financing decisions. However, their anticipated signs are ambiguous as there is no evidence that the two factors are key to a bank's approval of finance to SMEs. Form of business indicates an established business which is more easily able to borrow, or a business which is established because of the owner's wealth and which therefore has less need to borrow. On balance, the former appears more plausible, implying a possibly positive sign. On the other hand, enterprise size can be interpreted as a conventional corporate finance variable. Larger and prosperous businesses are probably more diversified and less risky than smaller and less prosperous businesses. This suggests that they should use more debt and less equity, ceteris paribus. However, there is the same ambiguity, as size could reflect either ability to borrow more, suggesting a positive sign or ability to borrow less, thus suggesting a negative sign. 


\subsection{Data presentation and Interpretation}

Logit coefficients, also known as effect coefficients, are used to estimate (predict) the odds that the dependent variable equals 1 . The log odds coefficients are used to compare the relative importance of the independent variables on the dependent $y=1$. If the logit for a given independent variable is $b_{1}$, then a unit increase in the independent variable is associated with $b_{1}$ unit increase in the log odds of the dependent variable (the natural log of the probability that the dependent $=1$ divided by the probability that the dependent $=0$ ). The probability that the dependent variable $=1$ is a function of the logit coefficients. For instance, $\mathrm{y}=1$ or $\mathrm{y}=0$ and $\mathrm{x}_{1}, \mathrm{x}_{2}$, and $\mathrm{x}_{3}$ are independent variables for the logistic model $\mathrm{y}=\mathrm{b}_{0}+\mathrm{b}_{1} \mathrm{x}_{1}+\mathrm{b}_{2} \mathrm{x}_{2}+\mathrm{b}_{3} \mathrm{x}_{3}$ and the probability of the dependent variable $\mathrm{p}(\mathrm{y}=1)=1 /[1+$ $\left.\mathrm{e}^{* *}-\left(\mathrm{b} 1 \mathrm{x} 1+\mathrm{b}_{2} \mathrm{x}_{2}+\mathrm{b}_{3} \mathrm{x}_{3}\right)\right]$.The sign of an estimated coefficient gives the direction of the effect of a change in the explanatory variable on the probability of $y=1$.

Table 1 presents the results for age of the business owner as a determinant of both longand short-term debt. From this it can be seen that there is a positive relationship between owner's age and external debt. Almost all the coefficients are positive in any of the equations of the model other than for borrowers within the18-29 year age brackets.

There is no significant relationship between form of business and long-term debt for SMEs in the study, but there is a significant relationship between form of business and use of personal savings, informal money lenders, retained earnings and sale of fixed assets. Table $3 a$ and $3 b$ show the results of the analysis for form of business and use of alternative sources of finance. In line with the pecking order theory, the results reveal that businesses with sole proprietorship give priority to personal savings as preferred source of finance while the partnership form of business depends on partnership contributions and sale of fixed assets. This theory helps to explain the observed differences between SMEs' and large enterprises' financial structures. The theory's application to SMEs implies that external equity finance issues may be inappropriate. In relation to the owner-manager's control over operations and assets, the internal equity finance will be preferred because this form of finance does not surrender control. The agency theory suggests that family owners and owner-managers prefer lower gearing to reduce the risk of their portfolios in the firm.

Collateral was strongly positively correlated with long-term bank finance for the SMEs in the study. The respondents were asked to rate the level of influence of the following factors on their access to bank finance (with special focus on collateral) on a scale of 1 to 4 ( 1 being very much or is applicable to my situation and 4 being undecided or not applicable to my situation), much was rated as 2 and not much as 3.

An examination of the data in the tables below shows the most important factors influencing gender access to bank finance. Male respondents cited collateral (a total rating of 75 per cent at 1 and 2 level), interest rate (a total rating of 71.8 per cent at 1 and 2 level), service fees (a total rating of 71.5 per cent at the 1 and 2 level) and relationship with bank (a total rating of 57 per cent at the 1 and 2 level). Similarly, female respondents cited collateral (a total rating of 86.8 per cent at 1 and 2 level), interest rate (a total rating of 82.9 per cent at level 1 and 2) and service fees (a total rating of 75 per cent at level 1 and 2) respectively. This result implies that female entrepreneurs face more serious constraints in accessing bank finance. 


\section{Table 1a}

Male-factors influencing access to bank finance, $\mathrm{N}=312$

\begin{tabular}{|l|c|c|c|c|c|c|c|c|c|c|}
\hline Factors & 1 & $\%$ & 2 & $\%$ & 3 & $\%$ & 4 & $\%$ & Total & $\%$ \\
\hline $\begin{array}{l}\text { Relationship } \\
\text { with bank }\end{array}$ & 134 & 42.9 & 44 & 14.1 & 66 & 21.2 & 68 & 21.8 & 312 & 100 \\
\hline $\begin{array}{l}\text { Limited range } \\
\text { of bank } \\
\text { products }\end{array}$ & 125 & 40.1 & 77 & 24.7 & 50 & 16 & 60 & 19.2 & 312 & 100 \\
\hline $\begin{array}{l}\text { Collateral } \\
\text { required }\end{array}$ & 180 & 57.7 & 54 & 17.3 & 19 & 6.1 & 59 & 18.9 & 312 & 100 \\
\hline Service fees & 127 & 40.7 & 96 & 30.8 & 23 & 7.4 & 66 & 21.2 & 312 & 100 \\
\hline $\begin{array}{l}\text { Bank failure to } \\
\text { understand our } \\
\text { business }\end{array}$ & 146 & 46.8 & 49 & 15.7 & 60 & 19.2 & 57 & 18.3 & 312 & 100 \\
\hline $\begin{array}{l}\text { Interest rate } \\
\text { charged }\end{array}$ & 177 & 56.7 & 47 & 15.1 & 19 & 6.1 & 69 & 22.1 & 312 & 100 \\
\hline
\end{tabular}

Table 1b

Female-factors influencing access to bank finance, $N=68$

\begin{tabular}{|l|c|c|c|c|c|c|c|c|c|c|}
\hline Factors & 1 & $\%$ & 2 & $\%$ & 3 & $\%$ & 4 & $\%$ & Total & $\%$ \\
\hline $\begin{array}{l}\text { Relationship } \\
\text { with bank }\end{array}$ & 34 & 42.9 & 9 & 13.2 & 13 & 19.1 & 12 & 17.6 & 68 & 100 \\
\hline $\begin{array}{l}\text { Limited range } \\
\text { of bank } \\
\text { products }\end{array}$ & 30 & 44.1 & 20 & 29.4 & 10 & 14.7 & 8 & 11.8 & 68 & 100 \\
\hline $\begin{array}{l}\text { Collateral } \\
\text { required }\end{array}$ & 52 & 76.5 & 7 & 10.3 & 4 & 5.9 & 5 & 7.4 & 68 & 100 \\
\hline Service fees & 37 & 54.4 & 14 & 20.6 & 11 & 16.2 & 6 & 8.8 & 68 & 100 \\
\hline $\begin{array}{l}\text { Bank failure to } \\
\text { understand our } \\
\text { business }\end{array}$ & 31 & 45.6 & 5 & 7.4 & 18 & 26.5 & 14 & 20.6 & 68 & 100 \\
\hline $\begin{array}{l}\text { Interest rate } \\
\text { charged }\end{array}$ & 51 & 75 & 4 & 5.9 & 4 & 5.9 & 9 & 13.3 & 68 & 100 \\
\hline
\end{tabular}

This indicates that access to bank finance is a problem for both male and female SME operators in Kenya. However, within this problem area, female entrepreneurs (respondents) felt that they were discriminated against more in terms of collateral and interest rate requirements than male respondents. This result confirms past findings by previous researchers. For example, a survey by African manufacturing enterprises in the manufacturing sectors of food, textile, wood and metal in Kenya, Cameron, Ghana, Zimbabwe and
Burundi found that most businesses find it difficult to raise capital. It was further found that most lending was collateralised and that the value of collateral was typically high. Many more businesses obtained overdrafts than bank loans (Bigstein et al.,_2001: 4). Lack of collateral was said to explain the mismatch between supply and demand in a small-scale financial market (Levisky, 1993: 9-10). This situation is further aggravated by limited reserve of personal savings and inadequacy of the capital markets (Evans \& Carter, 2000: 337). In addition, 
Hellman and Stiglitz (2000: 293) and Beck, Dermirgue-Kunt and Maksivomic (2002) have shown that small business operators are more credit constrained than large businesses.

Lutabingwa, Gray and Cooley (1996: 3) further pointed out the problem of credit inaccessibility in a study on sources of finance for small-scale manufacturing in Kenya. Similarly, the ODA and UNICEF report in Namusonge (1998) on sources of credit to micro and small enterprises (MSEs) in seven districts in Kenya indicated that SMEs did not have access to credit. The study showed that financial institutions were not favourable sources of credit. Seventy-two per cent of the respondents in the study observed that they had no access to credit due to lack of collateral and relevant information on existing sources of finance.

According to Soderbom (2001: 7), SMEs in Kenya seemed to receive little information and assistance regarding availability of finance from financial institutions and government departments. This hinders the development of the SME sector. Thus, research has shown that it is extremely difficult for micro and small entrepreneurs to access credit from traditional banks in Kenya. Lack of sufficient collateral covering the high risk involved, and small loan size requiring high transaction costs, are the main factors determining the negative attitude of banks. Nonetheless, the role of finance has been viewed as a critical element for the development of small and medium-sized enterprises.

Further to the continuum of factors influencing access to finance, enterprise age was found to have an influence on long-term and short-term debt. The pecking order theory suggests that the older the firm is, the more time it has to build up its internal resources from profitable trading. This relationship was significant for small and medium-sized enterprises in the study. However, the influence was statistically insignificant at 5 per cent significance level. Almost all the t-ratio values were far higher than the critical value of 1.98 (see tables 4 and 5).

Other studies in Kenya have identified a number of factors that affect the growth of the
SME sector. These factors include credit accessibility, technical training, poor management and accounting practices, information asymmetries associated with lending to small-scale borrowers, marketing, infrastructure and technology (see Ondiege 1995: 7; Daniels et al., 1995: 3; Namusonge, 1998). Consequently, small and medium-sized enterprises are susceptible to business failure primarily due to poor risk management associated with inadequately informed decision making.

\section{4}

\section{Conclusion and recommendation}

The results presented here confirm that there are strong relationships between collateral, enterprise size and age, and SMEs' financing structure. The results also indicate that for collateral and size, the relationship changes direction depending on whether long- or shortterm debt is considered. This reinforces the need to look at both long-term and short-term debt as well as total debt. The life-cycle, pecking order framework and agency theories hold up well, but do not appear to explain the financial structure of SMEs completely. Growth rate (life-cycle theory) was not found to be associated with SMEs' financing structure except for long-term debt. As far as agency theory is concerned, it is clear that collateral is important in raising long-term debt, but what is not so clear is why there is a strong negative relationship between collateral and short-term debt for small and medium-sized firms .

It was suggested that the central bank of Kenya legislate use of collateral substitutes to mitigate use of traditional forms of collateral. In addition, an SME information portal may be set up to address the current information gap in existing sources of finance and access conditions.

Finally, research on the use of collateral substitutes and on the relationship between collateral and short-term debt for SMEs may be considered. 


\section{Appendices}

\section{Table 1}

Age of owner-managers versus bank overdraft

Logit Maximum Likelihood Estimation

Dependent variable is OVERDRAFT

380 observations used for estimation from 1 to 380

\begin{tabular}{|c|c|c|c|}
\hline Regressor & Coefficient & Standard Error & T-Ratio [Prob] \\
\hline $18-29$ & -.51960 & 1.3537 & $-.38384[.701]$ \\
\hline $30-39$ & 2.1856 & .52667 & $4.1498[.000]$ \\
\hline $40-49$ & 2.5725 & .47293 & $5.4395[.000]$ \\
\hline $50-59$ & 2.4414 & .46590 & $5.2401[.000]$ \\
\hline $60+$ & 2.0130 & .37608 & $5.3526[.000]$ \\
\hline
\end{tabular}

Factor for the calculation of marginal effects $=.087282$

Mean of OVRD $=.92876$

Goodness of fit $=.93140$

\section{Table 2}

Age of owner-managers versus long-term loan

Logit Maximum Likelihood Estimation

Dependent variable is long-term loan

380 observations used for estimation from 1 to 380

\begin{tabular}{|c|c|c|c|}
\hline Regressor & Coefficient & Standard Error & T-Ratio [Prob] \\
\hline $18-29$ & -.29992 & 1.2932 & $-.23191[.817]$ \\
\hline $30-39$ & 1.9506 & .47695 & $4.0898[.000]$ \\
\hline $40-49$ & 2.1993 & .40443 & $5.4379[.000]$ \\
\hline $50-59$ & 2.6979 & .51618 & $5.2268[.000]$ \\
\hline $60+$ & 1.8931 & .35708 & $5.3017[.000]$ \\
\hline
\end{tabular}

Factor for the calculation of marginal effects $=.096474$

Mean of LTLOAN $=.92348$

Goodness of fit $=.92084$

Table $3 a$ and $3 b$

Alternative finance versus form of business

3a: Logit Maximum Likelihood Estimation

Dependent variable $=$ Sole proprietorship $(\mathrm{SP})$

380 Observations used for estimation from 1 to 380

\begin{tabular}{|l|c|c|c|}
\hline Regressor & Coefficient & Standard Error & T-Ratio [Prob] \\
\hline Personal savings & .66656 & .18166 & $3.6693[.000]$ \\
\hline Friends relatives & -.39316 & .22288 & $.7640[.079]$ \\
\hline Bank overdraft & -.10269 & .42585 & $-.24114[.810]$ \\
\hline Long-term loan & -.50842 & .43331 & $-1.1733[.241]$ \\
\hline
\end{tabular}




\begin{tabular}{|l|c|c|c|}
\hline Informal money lenders & .04908 & .33831 & $.14507[.885]$ \\
\hline Partner contributions & -1.3708 & .33733 & $4.0635[.000]$ \\
\hline Supplier credit & .61322 & .24791 & $2.4735[.014]$ \\
\hline Leasing & .015528 & .37325 & $.041601[.967]$ \\
\hline Hire purchase & .85678 & .58625 & $1.4614[.145]$ \\
\hline
\end{tabular}

Factor for the calculation of marginal effects $=.22639$

Mean of SP $=.61316$

Goodness of fit $=.62105$

\section{Table $3 b$}

Logit Maximum Likelihood Estimation

Dependent variable $=$ Partnership form of business (PAR)

380 observations used for estimation from 1 to 380

\begin{tabular}{|l|c|c|c|}
\hline Regressors & Coefficient & Standard Error & T-Ratio [Prob] \\
\hline Retained earnings & -1.1842 & .21330 & $-5.5520[.000]$ \\
\hline Guarantee scheme & -.45420 & .62745 & $-.72389[.470]$ \\
\hline Partner contributions & 1.9749 & 1.0425 & $1.8945[.059]$ \\
\hline SMEs L.scheme & -.67354 & .67391 & $-.99945[.318]$ \\
\hline Sale of fixed assets & .46724 & .29684 & $1.5740[.116]$ \\
\hline Municipal loan scheme & -.44095 & .29204 & $-1.5099[.132]$ \\
\hline Small business bank & .19524 & .39108 & $.49925[.618]$ \\
\hline
\end{tabular}

Factor for the calculation of marginal effects $=.17693$

Mean of PAR $=.22368$

Goodness of fit $=.76842$

\section{Table 4}

Long-term loan

Logit Maximum Likelihood Estimation

\begin{tabular}{|c|c|c|c|}
\hline \multicolumn{4}{|c|}{$\begin{array}{c}\text { Dependent variable }=\text { LONG TERM LOAN } \\
380 \text { observations used for estimation from 1 to } 380\end{array}$} \\
\hline Regressor & Coefficient & Standard Error & T-Ratio [Prob] \\
\hline$<1 \mathrm{yr}$ & -.29402 & 1.2920 & $-.22757[.820]$ \\
\hline $1-3$ & 1.9512 & .47693 & $4.0911[.000]$ \\
\hline $3-5$ & 2.1891 & .40470 & $5.4092[.000]$ \\
\hline $5-10$ & 2.6985 & .51617 & $5.2278[.000]$ \\
\hline $10+$ & 1.6949 & .36102 & $4.6948[.000]$ \\
\hline
\end{tabular}

Factor for the calculation of marginal effects $=.079599$

Mean of LTLOAN $=.92328$

Goodness of fit $=.92063$ 


\section{Table 5}

Overdraft

Logit Maximum Likelihood Estimation

\begin{tabular}{|c|c|c|c|}
\hline \multicolumn{4}{|c|}{$\begin{array}{c}\text { Dependent variable is OVERDRAFT } \\
380 \text { observations used for estimation from } 1 \text { to } 380\end{array}$} \\
\hline Regressor & Coefficient & Standard Error & T-Ratio [Prob] \\
\hline$<1 \mathrm{yr}$ & -.51151 & 1.3516 & $-.37845[.705]$ \\
\hline $1-3 \mathrm{yrs}$ & 2.1861 & .52665 & $4.1509[.000]$ \\
\hline $3-5 "$ & 2.5580 & .47330 & $5.4046[.000]$ \\
\hline $5-10 "$ & 2.4419 & .46589 & $5.2413[.000]$ \\
\hline $10+"$ & 1.9727 & .40266 & $4.8992[.000]$ \\
\hline
\end{tabular}

Factor for the calculation of marginal effects $=.066831$

Mean of OVERD $=.93122$

Goodness of fit $=.93386$

\section{References}

1 ANG, J.S. (1992) "On the theory of finance for privately held firms", Journal of Small Business Finance, 1(3): 185-203.

2 BATES, J. (1971) The Financing of Small Business, Sweet \& Maxwell: London.

3 BECK, T.; DEMIRGUC-KUNT, A. \& MAKSIMOVIC, V. (2002) "Financing patterns around the world: The role of institutions". World Bank Policy Research Working Paper, 2905, The World Bank: Washington, D.C.

4 BIGSTEN, A.; COLLIER, P.; DERCON, S.; FAFCHAMPS, M.; GAUTHIER, B.; GUNNING, J.; SODERBOM, M.; ODURO, A.; OOSTENDORP, R.; PATILLO, C.; TEAL, F. \& ZEUFACK, A. (2000) "Credit constraints in manufacturing enterprises in Africa. Center for the study of African economies", University of Oxford, WPS/2000.24; also: in: Journal of African Economies, (2003): 12-33.

5 BOLTON J.E. (1971) Small Firms, Report of the Committee of Inquiry on Small Firms, HMSO: London, Cmnd. 4811.

6 CRESSY, R. (1996) "Commitment lending under asymmetric information: Theory and tests on U.K", Startup Data, Small Business Economics 8(5): 397-408.

7 COSH, A.D. \& HUGHES, A. (1994) "Size, financial structure and profitability", Finance and the Small Firm, A. Hughes, \& D.J. Storey ed., Routledge: London: 284-315.
8 CHEHAB, A. (1995) "Essays on the determinants of capital structure", unpublished PhD. Dissertation, University of New Orleans:USA

9 CHITTENDEN, F.; HALL, G. \& HUTCHINSON, P. (1996) "Small firm growth, access to capital markets and financial structure: a review of issues and an empirical investigation", Small Business Economics, 8: 59-67.

10 EVANS, J.D. \& CARTER, S. (2000) Enterprise and Small Business: Principles, Practice and Policy, Pearson Education: Edinburgh.

11 DANIELS, L.C.; DONALD MEAD \& MUSINGA, M. (1995) "Employment and income in micro and small enterprises in Kenya, results of a 1995 survey", KREP Research Paper No 26, Nairobi.

12 FREEDMAN, J. \& GODWIN, M. (1994) "Incorporating the micro business", in Finance and the Small Firm, A. Hughes, \& D.J. Storey eds., Routledge: London: 18-63.

13 GARDNER, J.C. \& TRZINKA, C.A. (1992) "All-equity firms and the balancing theory of capital structure", Journal of Financial Research, 15: 77-90.

14 GUPTA, M.C. (1969) "The effects of size, growth and industry on the financial structure of manufacturing companies", Journal of Finance, 24: 517-529.

15 HELLMAN, T. \& STIGLITZ, J. (2000) "Credit and equity rationing in markets with adverse selection", European Economic Review, 44: 281304 . 
16 JORDAN, J.; LOWE, J. \& TAYLOR, P. (1998) "Strategy and financial in UK small firms", Journal of Business Finance and Accounting, 25(1): 1-27.

17 LEVY, B. (1993) “Obstacles to developing indigenous small and medium enterprises: an empirical assessment", The World Bank Economic Review, 7(1): 65-83.

18 LUTABINGWA, J.; COOLEY, W. \& GRAY, R.K. (1996) "Small scale manufacturing in Kenya: characteristics, problems and sources of finance", Online;Http://www.sbaer.uca.edu/ research/1996/USABSE/96usa 233txt. Accessed on 29.05 .03 (Conference paper).

19 LEVITSKY, J. (1993) "Credit guarantee funds and mutual guarantee systems”, SED, 7(2): 4-15.

20 MAKSIMOVIC, V.; LAEVEN, L.; DEMIRGUC-KUNT, A. \& BECK, T. (2004) "The determinants of financing obstacles". World Bank Policy Paper 3204, February.

21 MILLER, B. (1995) "Go with the cash flow", CA Magazine, Sept: 56-58.

22 MODIGLIANI, F. \& MILLER, M. (1958) "The cost of capital, corporation finance and the theory of investment", American Economic Review, 48: 261-297.
23 MYERS, S.C. (1977) "Determinants of corporate borrowing", Journal of Financial Economics, 5: 147-175.

24 NAMUSONGE, G.S. (1998) "Determinants of growth oriented small and medium enterprises in Nairobi, Kenya", PhD. Thesis;Nairobi, Jomo Kenyatta University of Agriculture and Technology.

25 ONDIEGE, P. (1995) "Informal sector development: Models and assistance program in Kenya", Final Report, Ottawa IDRC.

26 SODERBOM, M. (2001) "Constraints and opportunities in Kenyan manufacturing", Report on the Kenyan manufacturing Enterprise Survey 2000, Centre for the Study of African Economies, University of Oxford.

27 STOREY, D.; KEASEY, K.; WATSON, R.; \& WYNARCZYK, P. (1987) The Performance of Small Firms, Routledge: London.

28 STOREY, D.J. (1994) "The role of legal status in influencing bank financing and new firm growth", Applied Economics, 26: 129-136.

29 TITMAN, S. \& WESSELS, R. (1988) "The determinants of capital structure choice", Journal of Finance, 43(1): 1-19. 